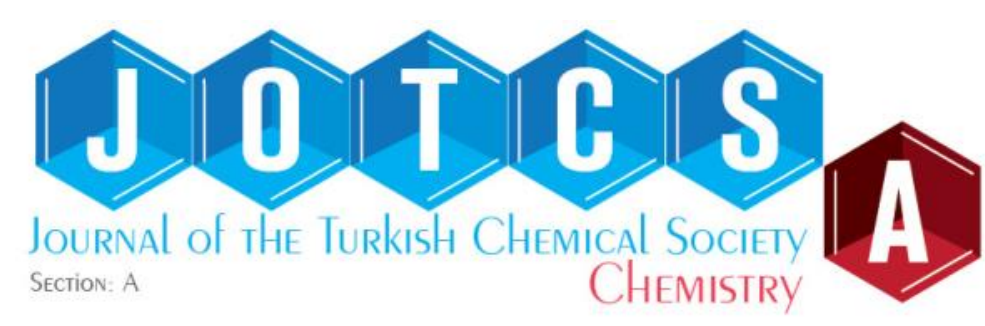

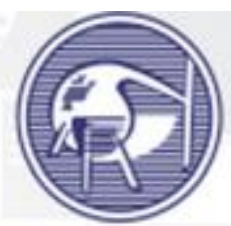

TURKISH

CHEMICAL SOCIETY

\title{
Spectrophotometric Determination of Sunset Yellow (E-110) in Powdered Beverages and Pharmaceutical Preparations after Cloud Point Extraction Method
}

\begin{abstract}
Tufan GÜRAY $*$ 国
${ }^{1}$ Eskisehir Osmangazi University, Faculty of Arts and Science, Department of Chemistry, 26480, Eskisehir, Turkey.

Abstract: In this study, Brij 58 was used for the spectrophotometric determination of sunset yellow (SY) (E-110) in pharmaceutical preparations and powdered beverages after cloud point extraction (CPE). Certain parameters such as $\mathrm{pH}$, surfactant concentration, extraction time and temperature, speed of centrifugation, and salt concentration were optimized. Linear range in the optimum conditions was $0.01-4.00 \mu \mathrm{g} \mathrm{mL}^{-1}$ and the correlation coefficient was 0.9995 . The limit of detection (LOD) and the limit of quantification (LOQ) of this method were $0.0078 \mu \mathrm{g} \mathrm{mL}^{-}$ 1 and $0.0261 \mu \mathrm{g} \mathrm{mL}^{-1}$, respectively.
\end{abstract}

Keywords: Brij 58; Sunset Yellow (E-110); Cloud Point Extraction (CPE); Spectrophotometric Determination; Surfactant

Submitted: November 05, 2017. Accepted: March 04, 2018.

Cite this: Güray T. Spectrophotometric Determination of Sunset Yellow (E-110) in Powdered Beverages and Pharmaceutical Preparations after Cloud Point Extraction Method. JOTCSA. 2018;5(2):479-92.

DOI: http://dx.doi.org/10.18596/jotcsa.349382.

*Corresponding author. E-mail: tguray@ogu.edu.tr; tufanguray@gmail.com 


\section{INTRODUCTION}

Food dyes are used to provide more attractive, appetizing appearances to enhance the taste, flavor, and color of foods (1). Food coloring Sunset Yellow (6-hydroxy-5- [(4-sulfophenyl) azo] -2-naphthalenesulfonic acid disodium salt) (SY) (E-110) is a food additive commonly used in foods, pharmaceuticals, and cosmetics. Nevertheless, it is vital that SY is one of the synthetic dyes most likely present in widespread food products that may lead to allergies, diarrhea, anxiety migraines and also could harm to the kidney and the liver if it is consumed to the extreme (24). It is also known as Orange Yellow S, INS No.110 and CI Food Yellow 3. Acceptable daily dose of SY, an azo dye, is $2.5 \mathrm{mg} \mathrm{kg}^{-1}$ (5). Nowadays, the use of such additives is taking much attention owing to a series of health risks induced by food dyes, since it plays an indispensable part in human public health (6). For this reason, it is imperative to make and monitor the identification of SY and similar azo dyes in various samples.

Several methods such as high performance liquid chromatography (HPLC) (7), capillary electrophoresis (CE) (8), thin layer chromatography (TLC) (9), voltammetry (10), and spectrophotometry (11) have been given in the literature for the determination of SY. These analytical methods require the use of harmful solvents especially for laboratory workers and the environment (12).

The cloud point extraction (CPE) method is also an alternative to other enrichment and separation methods as simple, sensitive, inexpensive, non-polluting, and environmentally sensitive (13). The aqueous solutions of nonionic surfactant materials become cloudy when their temperature reaches the cloud point temperature and analyte collapses with a small volume by a surfactant. The CPE procedure can also be termed as temperature induced phase separation or micelle-mediated extraction (14-16). Thus, CPE can lead to high recovery efficiency and a large preconcentration factor due to a very small volume of micellar phase binding the analyte that has been dispersed in the original matrix (17). CPE is not only preconcentration procedure but also a separation method.

Non-ionic surfactants such as Triton X-100 (18), Triton X-114 and Brij 56 (19) have been used for the determination of SY. To the best of our knowledge, there is no enrichment of the SY with CPE method using Brij 58, another non-ionic surfactant, in the literature.

In this study, it was aimed to develop a new method of CPE using Brij (polyethylene glycol hexadecyl ether) 58 for the first time the spectrophotometric determination of SY. 


\section{EXPERIMENTAL}

\section{Instrumentation}

Absorption spectra and absorbance measurements have been made by an Agilent (Stevens Creek Boulevard, Santa Clara, CA, USA) Transport 60 UV spectrophotometer. 1.00 cm lightbeam quartz cells have been used in these measurements. To measure the $\mathrm{pH}$ of the solutions, a ThermoOrion 720A model pH / ion counter (Beverly, MA, USA) with Orion 71-03 brand glass electrode has been used. Centrifugations were performed using a Sigma 1-6P (Osterode am Harz, Germany) centrifuge.

\section{Chemicals}

All the reagents are of analytical grade. Brij 58 (polyethylene glycol hexadecyl ether), Sunset Yellow (6-hydroxy-5- [(4-sulfophenyl) azo] -2-naphthalenesulfonic acid disodium salt) (SY), $\mathrm{CH}_{3} \mathrm{COOH}, \mathrm{H}_{3} \mathrm{PO}_{4}, \mathrm{NaOH}, \mathrm{HCl}, \mathrm{NaCl}, \mathrm{Na}_{2} \mathrm{CO}_{3}, \mathrm{NaH}_{2} \mathrm{PO}_{4}, \mathrm{Na}_{2} \mathrm{HPO}_{4}$, and anhydrous $\mathrm{Na}_{2} \mathrm{SO}_{4}$ were purchased from Sigma-Aldrich. All reagents were diluted using deionized water.

For the routine calibration and monitoring of our $\mathrm{pH}$ instruments, a ready-to-use buffer solutions with exact $\mathrm{pH}$ reference values $(\mathrm{pH} 4.01=$ citric acid/sodium hydroxide/hydrogen chloride, $\mathrm{pH}$ $7.00=$ di-sodium hydrogen phosphate/potassium dihydrogen phosphate, $\mathrm{pH}$ 10.04= boric acid/potassium chloride/sodium hydroxide in $20^{\circ} \mathrm{C}$, Merck) have been used. Buffer solutions $\left(\mathrm{pH}\right.$ 2-11) were prepared by using $0.04 \mathrm{M} \mathrm{H}_{3} \mathrm{PO}_{4}, 0.04 \mathrm{M} \mathrm{CH}_{3} \mathrm{COOH}, 0.2 \mathrm{M} \mathrm{NaH}_{2} \mathrm{PO}_{4}, 0.2 \mathrm{M}$

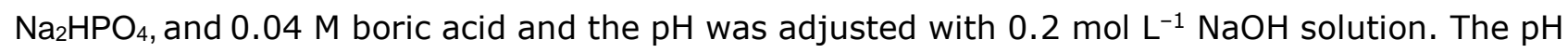
2 solution was prepared with $0.1 \mathrm{~mol} \mathrm{~L}^{-1} \mathrm{HCl}$.

Pharmaceutical preparations (Bemiks ${ }^{\circledR}$ tablets, Zentiva Health Products Industry and Trade Co., Kırklareli, Turkey; Magnorm ${ }^{\circledR}$ tablets, NEUTEC Ilac Sanayi ve Ticaret A.Ş., Istanbul, Turkey) and powdered beverage drinks have been purchased by pharmacies and local grocery stores.

\section{Preparation of Standard and Sample Solutions}

To prepare $100 \mu \mathrm{g} \mathrm{mL}^{-1}$ stock solution of SY, $0.1 \mathrm{~g}$ of the dye was dissolved in deionized water and diluted to $1000 \mathrm{~mL}$. with deionize water. The working standard solutions are prepared daily by diluting the desired concentrations from the stock solution. These solutions were stored in the dark at $4{ }^{\circ} \mathrm{C}$. To prepare Brij 58 solution of $20 \%(w / v)$, twenty grams of the Brij 58 is weighed and dissolved in $100 \mathrm{~mL}$ of deionized water in an ultrasonic bath.

Bemiks $^{\circledR}$ tablet contains vitamin B1, vitamin B2, vitamin B6, vitamin B12, folic acid, niacinamide, Ca-pantothenate and certain inactive ingredients, such as quinoline sarcine (E104), sunset yellow FCF (E110), titanium dioxide (E171), Ponceau 4R (E124). Ten Bemiks ${ }^{\circledR}$ tablets have been weighed and powdered. Accurately weighed $0.9496 \pm 0.0005 \mathrm{~g}$ (amount of 5 tablets) has been transferred to a $100 \mathrm{~mL}$ volumetric flask. The required volume with deionized water has been 
completed. Subsequently, an appropriate amount of this solution has been taken by filtration and used for the analysis.

Magnorm ${ }^{\circledR}$ tablet contains magnesium oxide and certain inactive ingredients, such as citric acid anhydrides, citric acid anhydrides, sodium hydrogen carbonate, povidone $\mathrm{K} 30$, sodium saccharin, sorbitol (E420), polyethylene glycol, aerosil 200, sunset yellow (E110), orange flavor, and apricot flavor. Ten Magnorm ${ }^{\circledR}$ tablets were powdered and mixed. An amount of $3.7885 \mathrm{~g}$ (1 tablet) was powdered and taken into a $500 \mathrm{~mL}$ volumetric flask. Then, the solution was diluted to $500 \mathrm{~mL}$ with deionized water. The $5 \mathrm{~mL}$ of this solution was taken and filtered, then the solution was diluted to $100 \mathrm{~mL}$ with deionized water.

The powdered beverage drink of $5.0000 \pm 0.0005 \mathrm{~g}$ has been weighed and taken into a $250 \mathrm{~mL}$ volumetric flask and the required volume was diluted with deionized water. Subsequently, appropriate amounts of this solution have been taken by filtration and they have been used for the analysis.

\section{Proposed CPE Method}

The method has applied to the standard solution of SY: A solution containing $8 \mathrm{~mL}$ of the buffered SY in $\mathrm{NaH}_{2} \mathrm{PO}_{4}$ and $\mathrm{Na}_{2} \mathrm{HPO}_{4}(\mathrm{pH} 6)$ has been transferred to a $15 \mathrm{~mL}$ screw-capped centrifuge tube (Figure 1a). $1 \mathrm{~mL}$ of $20 \%$ (w/v) Brij 58, $2.0050 \pm 0.0005 \mathrm{~g} \mathrm{Na}_{2} \mathrm{SO}_{4}$ were added and the solution has been diluted $10 \mathrm{~mL}$ with deionized water (Figure $1 \mathrm{~b}$ ). This mixture was immediately stirred until it was dissolved. The mixture left at $70^{\circ} \mathrm{C}$ for 15 minutes until a cloudy phenomenon occurred. Then it has been cooled down to the room temperature (Figure 1c). The mixture has been centrifuged at $4000 \mathrm{rpm}$ for 5 minutes for phase separation (Figure 1d). The surfactantrich phase has been separated and it has been collected on the top of the tube (Figure 1 e). Finally, the aqueous phase has been removed by means of a syringe and the surfactant-rich phase has been diluted with $1 \mathrm{~mL}$ of water and the absorbance of the solution was measured by UV-Vis. against blank at $482 \mathrm{~nm}$. 


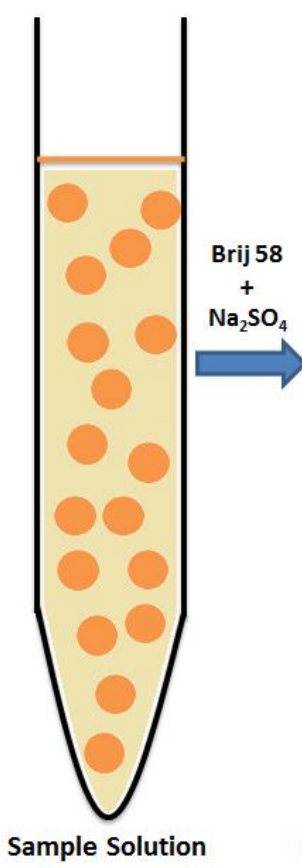

a

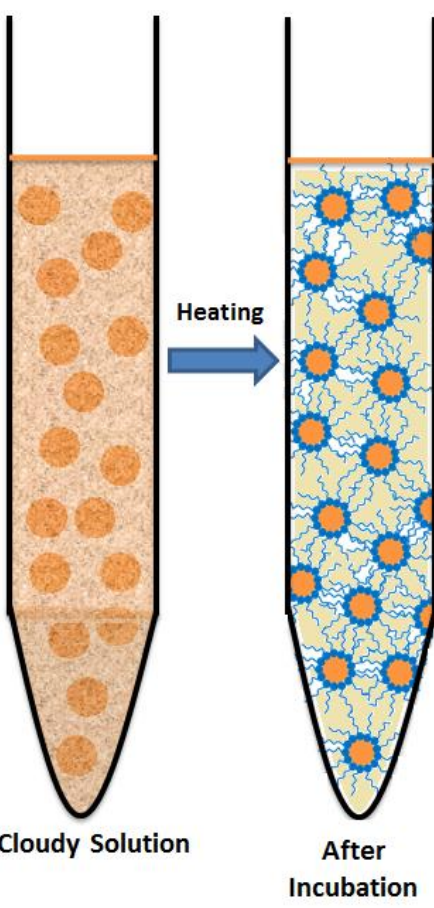

b

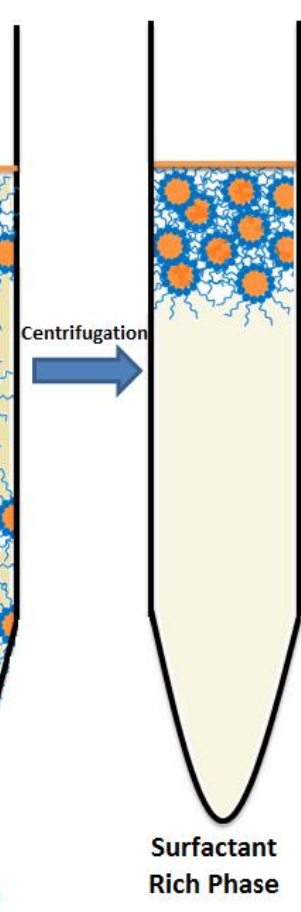

d

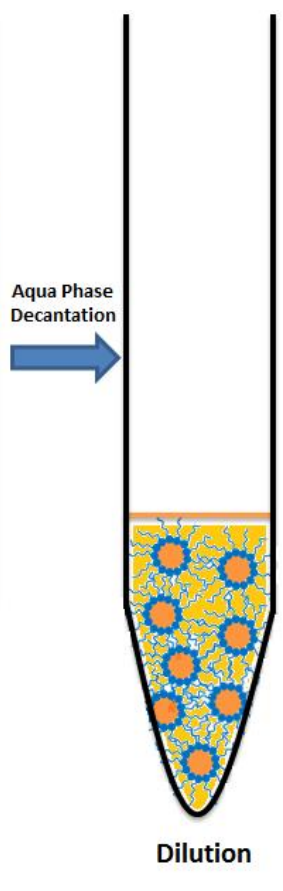

e

Figure 1: a- Sample solution, b- Mixture after Brij $58+\mathrm{Na}_{2} \mathrm{SO}_{4}$ added, c- After incubation, dAfter centrifugation, e-After decantation of $1 \mathrm{~mL}$ of water-soluble surfactant-rich phase.

The developed method has applied to two drugs and two powdered beverages as detailed in 'The preparation of standard and sample solutions' section in a preceding page.

\section{RESULT AND DISCUSSION}

The maximum absorbance of $0.01-4.00 \mu \mathrm{g} \mathrm{m}^{-1}$ the SY standard solution is $482 \mathrm{~nm}$ (Figure 2a). The surfactant (Brij 58) has been added to the medium. It did not make a significant change in the maximum wavelength of the dye by comparing the SY solution (Figure $2 b$ ). For this reason, all absorbance measurements have been made at this wavelength. The effects of the main variables in the CPE method such as the medium $\mathrm{pH}$ value, surfactant concentration, salt concentration, temperature, and time, have been optimized to achieve maximum sensitivity and recovery. 


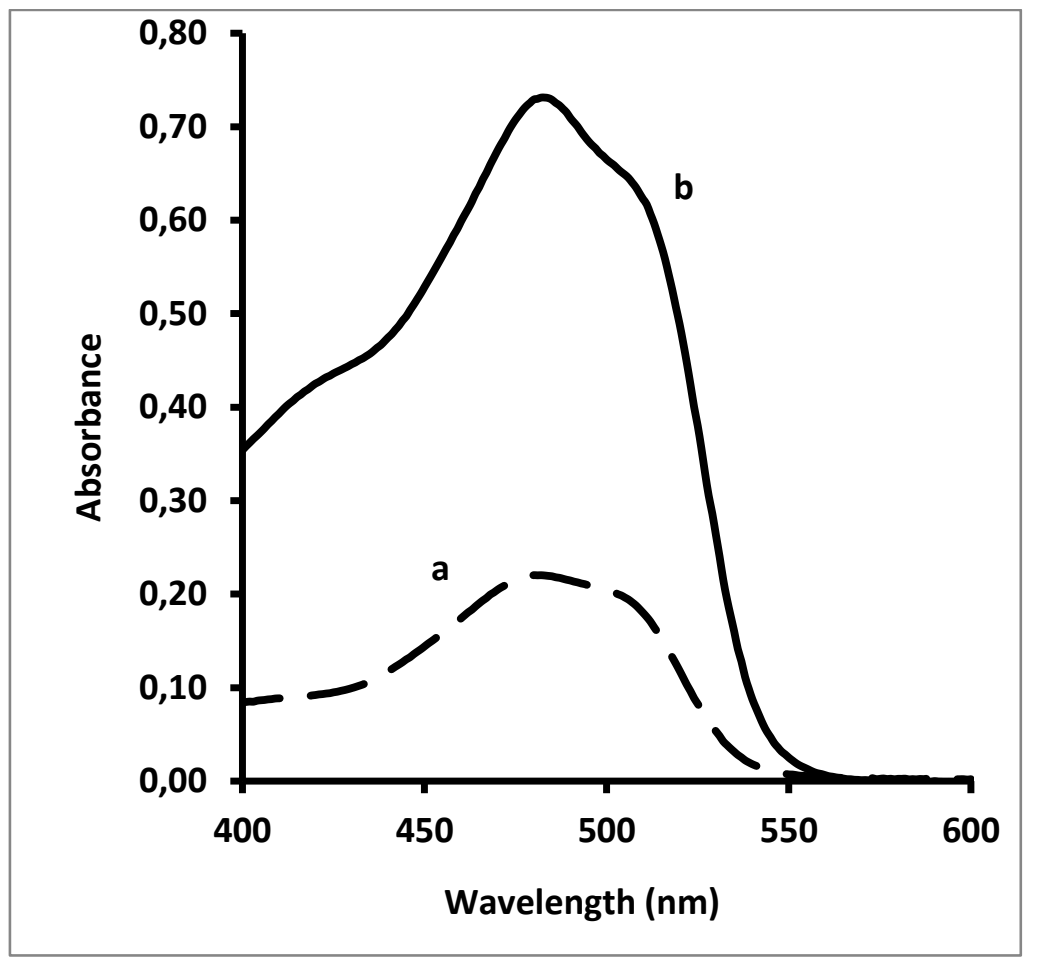

Figure 2: Absorption spectra for $4 \mu \mathrm{g} \mathrm{mL}^{-1} \mathrm{SY}$, a- without extraction, b- after CPE.

\section{The Effect of pH}

In the CPE procedure, the $\mathrm{pH}$ is an important parameter that increases the coefficient of dispersion of the analyte between the aqueous phase and the surfactant-rich phase. For this reason, the $\mathrm{pH}$ effecting on SY extraction efficiency has been examined between $\mathrm{pH} 2$ and 11 . The $\mathrm{pH}$ of the solution was adjusted to the desired value by the addition of hydrochloric acid and sodium hydroxide and using a $\mathrm{pH}$ meter. The SY solution was prepared in detail in the section of 'Proposed CPE Method'. The absorbance of the SY has been measured at $482 \mathrm{~nm}$ (Figure 3). The increase has been observed in absorbance up to $\mathrm{pH} 6$ and, then the absorbance did not change too much up to $\mathrm{pH}$ 8. The results indicate the range of $\mathrm{pH} \mathrm{6-8} \mathrm{is} \mathrm{most} \mathrm{suitable} \mathrm{for} \mathrm{dye}$ in the viewpoint of CPE efficiency and the $\mathrm{pH}$ range was selected as an optimum $\mathrm{pH}$. All the studies have been carried out at $\mathrm{pH}$ 6-8. 


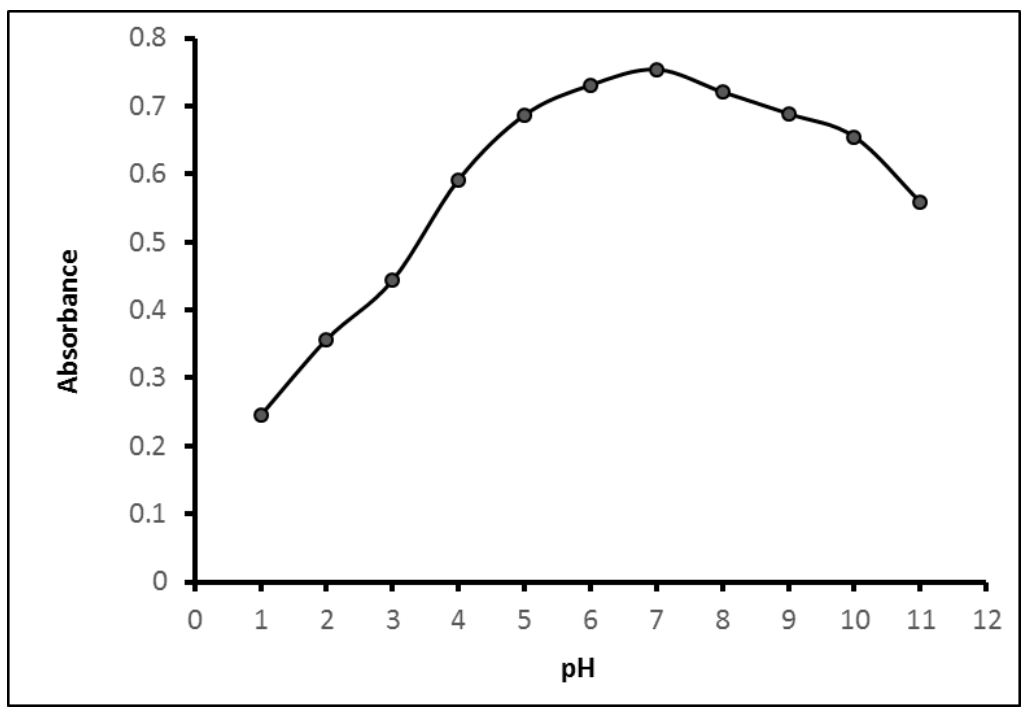

Figure 3: Effect of pH on CPE efficiency. $4 \mu \mathrm{g} \mathrm{mL}^{-1} \mathrm{SY}, 2 \%$ Brij 58, $2.00 \mathrm{~g} \mathrm{Na}_{2} \mathrm{SO}_{4}$, incubation at $70^{\circ} \mathrm{C}$ for 15 minutes.

\section{The Effect of Surfactant Concentration}

Optimizing the concentration of the surfactant is one of the important parameters to increase extraction efficiency. Thus, the effect of concentration of Brij 58 on the absorbance of the SY has been studied. The results are given in Figure 4. As can be seen, the absorbance does not change at concentrations greater than $2 \%(w / v)$ of Brij 58. For this reason, $2 \%(w / v)$ Brij 58 has been used throughout the study.

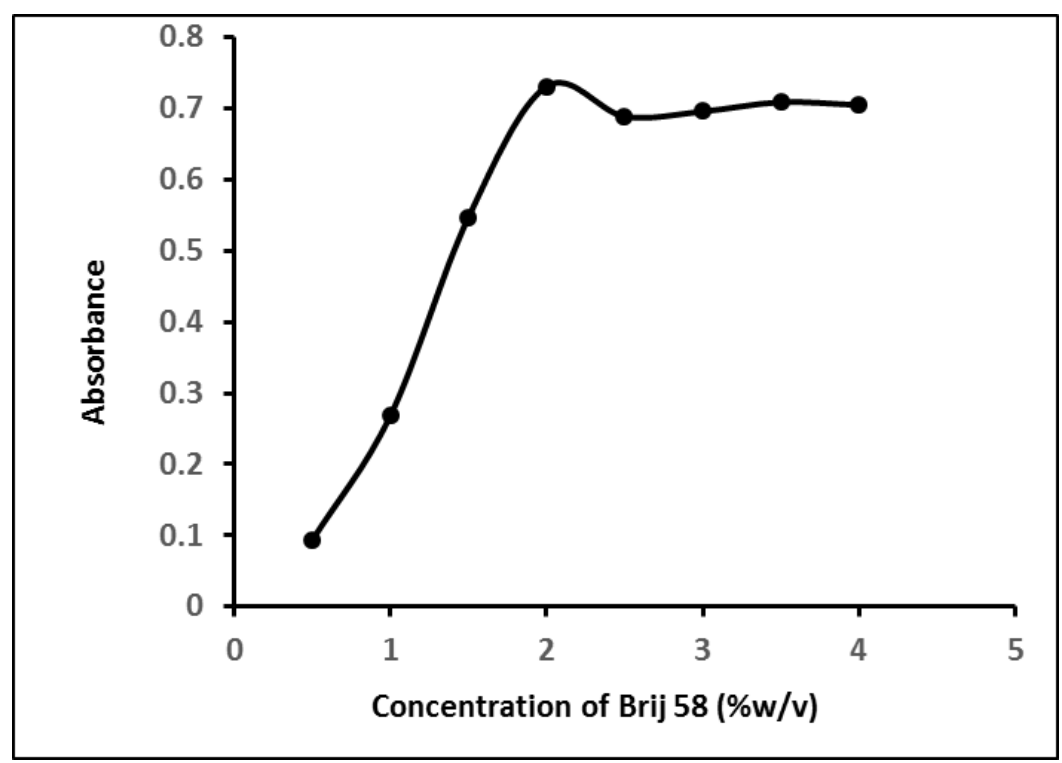

Figure 4: The effect of Brij 58 concentration on the CPE efficiency of SY. $4 \mu \mathrm{g} \mathrm{mL}^{-1} \mathrm{SY}, \mathrm{pH} 6$, $2.00 \mathrm{~g} \mathrm{Na}_{2} \mathrm{SO}_{4}, 15$ minutes of incubation time at $70^{\circ} \mathrm{C}$.

\section{The Effect of Salt}

A salt concentration is important in the CPE procedure because it helps the phase separation, to increase the mass transfer of the analyte from the aqueous phase to the surfactant-rich phase and to reduce the cloud point temperature. For these reasons, the commonly used salts such as $\mathrm{NaCl}, \mathrm{Na}_{2} \mathrm{SO}_{4}$ and $\mathrm{Na}_{2} \mathrm{CO}_{3}$ have been tried and their effects on the extraction process have been 
investigated. The surfactant-rich phase has not been separated or the surfactant-rich phase was too poor to be separated when other salts were used. So, a $20 \%$ (w/v) concentration of $\mathrm{Na}_{2} \mathrm{SO}_{4}$, which maximizes the absorption of SY, has been selected as the optimum salt concentration. The results are given in Figure 5.

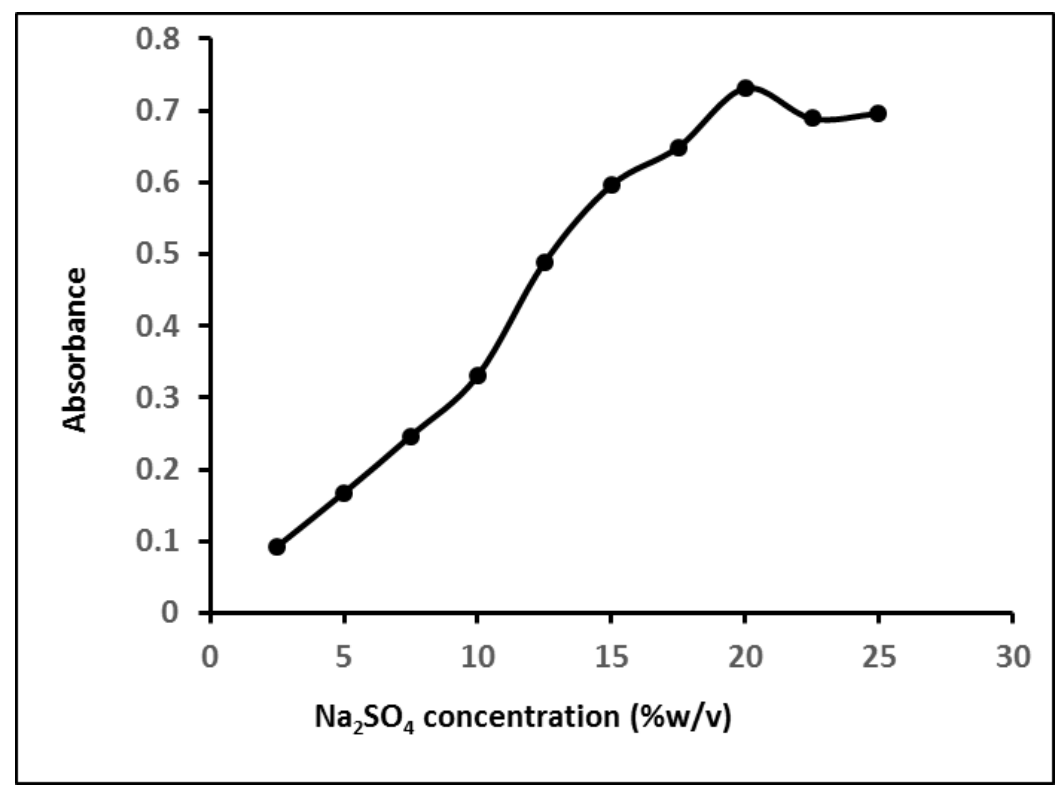

Figure 5: The effect of $\mathrm{Na}_{2} \mathrm{SO}_{4}$ concentration on the CPE efficiency of SY. $4 \mu \mathrm{g} \mathrm{mL}^{-1} \mathrm{SY}, \mathrm{pH}=6$, $2 \%(\mathrm{w} / \mathrm{v})$ Brij 58,15 minutes of incubation time at $70^{\circ} \mathrm{C}$.

\section{Effect of Equilibrium Temperature and Incubation Time}

Two other important parameters examined in the CPE procedure are the equilibrium temperature and incubation time. The studied temperature ranges were $50-90{ }^{\circ} \mathrm{C}$ and the highest extraction efficiency was observed at $70^{\circ} \mathrm{C}$. The incubation time in the range of 10-40 min has been studied. The maximum absorbance has been obtained for $15 \mathrm{~min}$. In further studies, these optimum conditions have been carried out.

\section{The Effect of Interference Ions}

In this study, the effect of different anions and cations on the determination of $5 \mathrm{ppm}$ SY has been studied by the proposed method. The tolerance limit has been examined taking into account the amount of foreign species causing the absorbance change of less than $\pm 5 \%$. The results are given in Table 1. 
Table 1: Comparison of the effect of interfering species on the determination of SY in the

\begin{tabular}{ll}
\multicolumn{2}{l}{ optimum conditions, $\mathrm{CSY}=4 \mathrm{mg} \mathrm{L}^{-1}}$. \\
species (I) & $\begin{array}{l}\text { Limiting mass } \\
\text { ratio (SY: I) }\end{array}$ \\
\hline $\mathrm{K}^{+}, \mathrm{Mg}^{2+}, \mathrm{Na}^{+}$ & $1: 2000$ \\
$\mathrm{Hg}^{2+}, \mathrm{Mn}^{2+}, \mathrm{Pb}^{2+}, \mathrm{Be}^{2+}, \mathrm{Fe}^{3+}, \mathrm{Al}^{3+}, \mathrm{Sr}^{2+}, \mathrm{Sn}^{2+}$ & $1: 100$ \\
$\mathrm{Co}^{2+}, \mathrm{Zn}^{2+}, \mathrm{Ni}^{2+}, \mathrm{Cd}^{2+}, \mathrm{Si}^{2+}$ & \\
$\mathrm{F}^{-}, \mathrm{Cl}^{-}, \mathrm{Br}^{-}, \mathrm{I}^{-}, \mathrm{NO}_{3}-, \mathrm{SO}_{4}^{2-}$ & $1: 4000$ \\
$\mathrm{AsO}_{4}^{-}, \mathrm{B}_{4} \mathrm{O}_{7}^{2-}, \mathrm{HPO}_{4}^{2-}, \mathrm{SCN}^{-}$ & $1: 200$ \\
\hline
\end{tabular}

\section{Analytical Performance}

Correlation graphs with the proposed method have been obtained in the optimal conditions between increasing concentrations of SY versus the measured absorbance.

Absorbance of the SY obeys Beer's law between $0.01 \mu \mathrm{g} \mathrm{mL}^{-1}$ and $4.00 \mu \mathrm{g} \mathrm{mL}^{-1}$ in the optimum conditions. The correlation coefficient for the SY is 0.9995 . The value of slope is 0.2105 and the intercept is +0.0237 . Thus, the calibration equation was $A=0.2105 \mathrm{C}\left(\mu \mathrm{g} \mathrm{mL}^{-1}\right)+0.0237$.

The accuracy of this method was determined by performing five repetitions of $0.80 \mu \mathrm{g} \mathrm{mL}^{-1} \mathrm{SY}$. The RSD value is $1.44 \%$. The limit of detection (LOD) of the method is $0.0078 \mu \mathrm{g} \mathrm{mL}^{-1}$ depending on the standard deviation of blank with repetition number of 3 .

\section{Sample Application of the Proposed CPE Method}

This method has been applied to the spectrophotometric determination of SY in two different drug samples and two different powdered beverages. The analysis of the SY in the samples was realized as stated in the experimental section of 'Proposed CPE Method'. Recovery experiments were performed by spiking the samples prior to the CPE with the addition of known amounts of SY. The recovery values obtained from the results in Table 2 are between $96.88 \%$ and $103.75 \%$. According to these values, it can be said that the materials present in the samples do not interfere with the developed method. The acceptable Daily Intake for SY has been given as 0.0$2.5 \mathrm{mg} / \mathrm{kg}$ body weight by World Health Organization (WHO) (2). The results show that the developed CPE method can be used for the accurately determination of SY in these samples. 
Table 2: The spectrophotometric determination of SY in powdered beverages and pharmaceutical preparations after the developed CPE.

\begin{tabular}{|c|c|c|c|}
\hline Sample & $\begin{array}{l}\text { Added, SY } \\
\left(\mu \mathbf{g ~ m L}^{-1}\right)\end{array}$ & $\begin{array}{l}\text { Found, } \mathbf{S Y} \pm \mathbf{C L}^{\mathbf{a}} \\
\left(\mu \mathbf{g ~ m L}^{-1}\right)\end{array}$ & Recovery', \% \\
\hline \multirow[t]{3}{*}{ Powdered beverage 1} & - & $0.95 \pm 0.11$ & - \\
\hline & 0.80 & $1.74 \pm 0.15$ & 98.75 \\
\hline & 1.60 & $2.51 \pm 0.15$ & 98.13 \\
\hline \multirow[t]{3}{*}{ Powdered beverage 2} & - & $2.16 \pm 0.01$ & - \\
\hline & 0.80 & $2.95 \pm 0.07$ & 99.24 \\
\hline & 1.60 & $3.78 \pm 0.06$ & 100.99 \\
\hline \multirow[t]{3}{*}{ Magnorm ${ }^{\circledR}$ (Pharmaceutical preparation) } & - & $1.46 \pm 0.06$ & - \\
\hline & 0.80 & $2.26 \pm 0.07$ & 101.25 \\
\hline & 1.60 & $3.06 \pm 0.16$ & 96.88 \\
\hline \multirow[t]{3}{*}{ Bemiks $^{\circledR}$ (Pharmaceutical preparation) } & - & $0.78 \pm 0.07$ & - \\
\hline & 0.80 & $1.61 \pm 0.10$ & 103.75 \\
\hline & 1.60 & $2.30 \pm 0.07$ & 98.13 \\
\hline
\end{tabular}

${ }^{\text {a } C L}$ is confidence limits, $\left(\frac{t s}{\sqrt{n}}\right) ; \mathrm{n}=5$

${ }^{\text {bRecovery }}=\frac{\left(C_{2}-C_{1}\right)}{C_{3}} \times 100$

$C_{1}=$ Measured sample concentration (blank)

$C_{2}=$ The measured "spiked sample" concentration (blank + spike)

$C_{3}=$ Spike concentration

\section{Comparison of the Proposed Method with Literature}

An comparison of some apparent features of the developed method with other reported methods for the simultaneous determination of SY in various samples is shown in Table 3. All existing methods for SY are based on CPE. The LOD value obtained for SY in the present work is superior compared to some of these methods $(12,20)$. While the method is slightly less sensitive compared to the other two methods $(18,19)$, these methods have certain disadvantages. ElShahawi MS, et al. used an extra chemical such as trioctylamine to increase the efficiency of their work (18) and the repeatability of study of Heydari R. et al. is low (19). Among the values in Table 3, our method has the widest linear range and almost the lowest LOD with a high recovery. 
Table 3: Comparison of certain CPE methods for spectrophotometric determination of SY reported in the literature.

\begin{tabular}{|c|c|c|c|c|c|c|c|c|c|c|c|c|}
\hline Surfactant & Salt & pH & $\begin{array}{l}\text { Inc. }^{a} \\
\text { Temp. } \\
\left({ }^{\circ} \mathrm{C}\right)\end{array}$ & $\begin{array}{l}\text { Inc. }^{a} \\
\text { Time } \\
\text { (min) }\end{array}$ & $\begin{array}{l}\text { Centr.' } \\
\text { Time } \\
\text { (min.) }\end{array}$ & $\begin{array}{l}\text { Solvent } \\
\text { of } \\
\text { Dilution }\end{array}$ & $\begin{array}{l}\text { Linear } \\
\text { Range } \\
\mu \mathrm{g} \mathrm{mL}^{-1}\end{array}$ & $\begin{array}{l}\text { LOD } \\
\mu \mathrm{g} \mathrm{mL} \mathrm{mL}^{-1}\end{array}$ & $\begin{array}{l}\text { RSD } \\
\%\end{array}$ & $\begin{array}{l}\text { Recovery } \\
\%\end{array}$ & Remarks & Ref. \\
\hline $\begin{array}{l}\text { Triton X-100 } \\
0.03 \mathrm{M}, 4 \mathrm{~mL}\end{array}$ & $\begin{array}{l}\mathrm{Na}_{2} \mathrm{SO}_{4} \\
1 \mathrm{M}, 1 \mathrm{~mL}\end{array}$ & $\begin{array}{l}\mathrm{HCl} \\
0.01 \mathrm{M}\end{array}$ & 70 & 10 & 10 & $\begin{array}{l}\mathrm{MeOH} \\
0.1 \mathrm{~mL}\end{array}$ & $\begin{array}{l}0.020- \\
0.452\end{array}$ & $5.0 \times 10^{-3}$ & 1.49 & 96.79 & $\begin{array}{l}\text { Trioctylamine was } \\
\text { used to increase } \\
\text { efficiency }\end{array}$ & (18) \\
\hline $\begin{array}{l}\text { Triton X-100 } \\
200 \mathrm{~g} / \mathrm{L}, 3 \mathrm{~mL}\end{array}$ & $\begin{array}{l}\mathrm{Na}_{2} \mathrm{SO}_{4} \\
1 \mathrm{M}, 5 \mathrm{~mL}\end{array}$ & - & 40 & 10 & 10 & $\begin{array}{l}\text { Water } \\
5 \mathrm{~mL}\end{array}$ & $20-120$ & 5.0 & 1.97 & 94.75 & LOD is high & (12) \\
\hline $\begin{array}{l}\text { Triton X-114 } \\
200 \mathrm{~g} / \mathrm{L}, 2 \mathrm{~mL}\end{array}$ & $\begin{array}{l}\mathrm{Na}_{2} \mathrm{SO}_{4} \\
1 \mathrm{M}, 5 \mathrm{~mL}\end{array}$ & - & 40 & 10 & 10 & $\begin{array}{l}\text { Water } \\
5 \mathrm{~mL}\end{array}$ & $20-120$ & 10.4 & 1.13 & 91.72 & LOD is high & (12) \\
\hline $\begin{array}{l}\text { Brij } 56 \\
200 \mathrm{~g} / \mathrm{L}, 3 \mathrm{~mL}\end{array}$ & $\begin{array}{l}\mathrm{Na}_{2} \mathrm{SO}_{4} \\
1 \mathrm{M}, 5 \mathrm{~mL}\end{array}$ & - & 60 & 15 & 10 & $\begin{array}{l}\text { Water } \\
5 \mathrm{~mL}\end{array}$ & $20-120$ & 2.8 & 1.06 & 89.13 & LOD is high & (12) \\
\hline $\begin{array}{l}\text { Triton X-100 } \\
\% 40,1.5 \\
\mathrm{~mL}\end{array}$ & $\begin{array}{l}\mathrm{NaCl} \\
1.5 \mathrm{~g}\end{array}$ & 6 & 55 & 15 & 5 & $\begin{array}{l}\text { Water } \\
1 \mathrm{~mL}\end{array}$ & $\begin{array}{l}0.025- \\
1.300\end{array}$ & $6.0 \times 10^{-3}$ & 3.35 & 98.64 & $\begin{array}{l}\text { Repeatability is } \\
\text { low }\end{array}$ & (19) \\
\hline $\begin{array}{l}\text { Triton X-100 } \\
0.5 \mathrm{M}, 4.5 \mathrm{~mL}\end{array}$ & $\begin{array}{l}\mathrm{KCl} \\
1 \mathrm{M}, 5 \mathrm{~mL}\end{array}$ & 4 & 80 & 40 & - & $\begin{array}{l}\text { Water } \\
5 \mathrm{~mL}\end{array}$ & $\begin{array}{l}0.020- \\
4.000\end{array}$ & $9.0 \times 10^{-3}$ & 3.50 & 99.80 & $\begin{array}{l}\text { Repeatability is } \\
\text { low }\end{array}$ & (20) \\
\hline $\begin{array}{l}\text { Brij } 58 \\
\% 20,1 \mathrm{~mL}\end{array}$ & $\begin{array}{l}\mathrm{Na}_{2} \mathrm{SO}_{4} \\
2 \mathrm{~g}\end{array}$ & 6 & 70 & 15 & 5 & $\begin{array}{l}\text { Water } \\
1 \mathrm{~mL}\end{array}$ & $\begin{array}{l}0.010- \\
4.000\end{array}$ & $7.8 \times 10^{-3}$ & 1.44 & $99.64^{c}$ & & $\begin{array}{l}\text { This } \\
\text { work }\end{array}$ \\
\hline
\end{tabular}

anc.: Incubation, ${ }^{\mathrm{b} C e n t r .:}$ Centrifugation, ${ }^{\mathrm{c}} \overline{\mathrm{X}}$ : Recovery (\%) average in Table 2. 


\section{CONCLUSION}

The developed CPE technique has advantages such as low cost, sensitiveness, selectiveness, high extraction efficiency, and environmentally friendliness. Brij 58 was used, for the first time, as a surfactant for the determination of SY after CPE method. This new CPE spectrophotometric method can be used for the sensitive, selective and reproducible determination of SY in short time in routine analysis.

\section{ACKNOWLEDGEMENT}

The author is grateful to Prof. Dr. Ülkü Dilek UYSAL for her help.

\section{REFERENCES}

1. Pourreza N, Elhami S. Cloud point extraction and spectrophotometric determination of amaranth in food samples using nonionic surfactant triton X-100 and tetrabutylammonium hydrogen sulfat. Journal of The Iranian Chemical Society. 2009;6(4): 784-788.

2. Miao X, Wang W, Xiong B, Zhou X, Hu J. A separation-free method for simultaneous determination of sucrose and sunset yellow in different abundance by integrating RBI and TL detectors Analytical Methods. 2011; 3(3):514-518.

3. Minioti KS, Sakellariou CF, Thomaidis NS. Determination of 13 synthetic food colorants in water-soluble foods by reversed-phase high-performance liquid chromatography coupled with diode-array detector. Analytica Chimica Acta.2007; 583(1): 103-110.

4. Yadav A, Kumar A, Dwivedi PD, Tripathi A, Das $M$. In vitro studies on immunotoxic potential of Orange II in splenocytes. Toxicology Letters. 2008; 208(3): 239-245.

5. Joint FAO/WHO Expert Committee on Food Additives, Compendium of Food Additive Specifications. FAO JECFA Monographs 5, 2008; 69th 79-82.

6. Zhu J, Liu S, Liu Z, Li Y, Tian J, Hu X. A highly sensitive and selective assay of doxycycline by dualwavelength overlapping resonance Rayleigh scattering. Spectrochimica Acta Part A: Molecular and Biomolecular Spectroscopy. 2014; 124: 237-248.

7. Gosetti F, Gianotti V, Polati S, Gennaro MC. HPLC-MS degradation study of E110 Sunset Yellow FCF in a commercial beverage. Journal of Chromatography A. 2005;1090: 107-115.

8. Del Giovine L, Bocca AP. Determination of synthetic dyes in ice-cream by capillary electrophoresis. Food Control. 2003;14: 131-135.

9. Soponar F, Mot AC, Sarbu C. Quantitative determination of some food dyes using digital processing of images obtained by thin-layer chromatography. Journal of Chromatography A. 2008;1188: 295-300.

10. Ni YN, Bai JL, Simultaneous determination of Amaranth and Sunset Yellow by ratio derivative voltammetry. Talanta. 1997:44; 105-109.

11. Dinc E, Baydan E, Kanbur M, Onur F. Spectrophotometric multicomponent determination of sunset yellow, tartrazine and allura red in soft drink powder by double divisor-ratio spectra derivative, inverse least-squares and principal component regression methods. Talanta. 2002;58: 579-594.

12. Wang Y, Zhang Z, Xiao Y, Li N. Spectrophotometric determination of Sunset Yellow in beverage after preconcentration by the cloud point extraction method. Analytical Methods. 2014;6: 8901-8905.

13. Kaur A, Gupta U. The review on spectrophotometric determination of synthetic food dyes and lakes. Gazi University Journal of Sciences. $2012 ; 25(3)$ : 579-588. 
14. Saitoh $T$, Tan $H$, Watanabe $H$, Kamidate $T$. Phase separation in aqueous micellar solutions of nonionic surfactants for protein separation. Trends in Analytical Chemistry. 1995; 14(5): 213-217.

15. Hinze WL, Pramauro E. A Critical Review of Surfactant-Mediated Phase Separations (Cloud-Point Extractions): Theory and Applications Journal C R C Critical Reviews in Analytical Chemistry 1993; 24(2): 133-177.

16. Tani H, Kamidate T, Watanabe H. Micelle-mediated extraction. Journal of Chromatography A. 1997; 780(1-2): 229-241.

17. Escaleira LA, Santelli RE, Oliveira EP, de Fátima M, de Carvalho B, Bezerra MA. Preconcentration procedure for determining trace amounts of $\mathrm{Ni}, \mathrm{Cd}, \mathrm{Pb}$ and $\mathrm{Cu}$ in high-salinity waters after cloud-point extraction. International Journal of Environmental Analytical Chemistry. 2009; 89(7): 515-527.

18. El-Shahawi MS, Hamza A, Al-Sibaai AA. Bashammakh AS, Al-Saidi HM. A new method for analysis of sunset yellow in food samples based on cloud point extraction prior to spectrophotometric determination. Journal Industrial and Engineering Chemistry. 2013;19: 529-535.

19. Heydari R, Hosseini M, Alimoradi M, Zarabi S. A simple method for simultaneous spectrophotometric determination of brilliant blue FCF and sunset yellow FCF in food samples after cloud point extraction. Journal of Chemical Society Pakistan. 2016;38: 438-445.

20. Heidarizadi E, Tabaraki R. Simultaneous spectrophotometric determination of synthetic dyes in food samples after cloud point extraction using multiple response optimizations. Talanta. 2016;148: 237246. 
